out the Presidency. A Committee was appointed, but there was some difference of opinion amongst the members as to the most convenient standard. Some were in favour of adopting the scale used by the railway companies in Bombay-that is, 180 grains $=\mathbf{I}$ tola, and so on up to $\mathbf{I}$ candy ; but the majority thought that the English system of hundredweights, quarters, and pounds would be the best, and to this view the Chambers of Commerce of Bengal, Madras, and Kurrachee have assented. The Committee, however, refrained from urging on the Government to alter the present standards. The Government of India have appointed a Commission to inquire into the whole matter.

M. RESin has published, in the Irvestia of the Russian Geographical Society, interesting sketches of the natives of Kamchatka, made during a cruise on the schooner Sibir. It appears that the Kamchadales and the Aleutes are rapidly abandoning their mother language, and speak a very broken Russian-the more broken as the Russians themselves, in order to be better understood, speak a language which has hardly any likness to their mother tongue. The population of Kamchatka, which was carefully registered in 1878 and 1879 , shows a regular decrease ; since the time of Krasheninnikoff's journey (in I 74I) the population seems to have been reduced to one-half of what it was 148 years ago. Years of scarcity of fish, the staple food of the population, are quite common. In such cases the Lamites and the Koryaks usually bring to the Kamchadales a number of their reindeer; but this voluntary holp is not sufficient to prevent starvation. Hunting becomes less and less profitable. The following figures represent the results of hunting during the winter of $1884-85$ : 2,9I 5 sables, I 59 foxes, $32 \mathrm{I}$ otters, 302 ermines, 120 mountain sheep, and 767 reindeer. It is noteworthy that no diminution of population is remarked among the Tchukches on the coasts of the Arctic Ocean.

LAST week we quoted from Prjevalsky's “ Fourth Journey to Central Asia" a description of fiery sunsets he had observed in crossing the Gobi. The same work contains the following remarks as to the action of wind upon the soil in the deserts of Central Asia :- "One must see the wind blowing in the desert to appreciate its force. Not only dust and sand fill the atmosphere, but sometimes smaller gravel is lifted into the air, while larger stones are rolled over the surface of the soil. At the foot of the Altyn-tagh, in the neighbourhood of the Lob-nor, we saw how stones as big as a man's fist, having been whirled into the hollow of a larger piece of rock by the storm, were making deep holes, and had even pierced through a slab of sandstone 2 feet thick." In accordance with Richthofen's views, Prjevalsky was inclined to explain the formation of loess by the force of wind, but he was not aware of the geographical distribution of loess-that is, its disposition as a girdle along the foot of all the mountains of Central Asia, and its absence on the plateaus, even in the parts which are protected from wind. On the other hand, the winds of the desert really afford an explanation of the strange coarse gravel, quite devoid of any particles of finer sand and loam, which covers the Gobi. The winds must have blown away the finer parts of the gravel.

WE have received the Triennial Calendar of the Tungwen College of Pekin, at which over a hundred students are prepared for the Government service. The full course, literary and scientific, extends over eight years, the first three being devoted exclusively to foreign languages, and the remainder to the acquisition of scientific and general knowledge through the medium of these languages. After the completion of the general course, students may, if they please, remain in the College, or be sent abroad at the option of the Grovernment, for the pursuit of special studies with a view to professional use. The method of paying the students is thus described in the
Calendar :- The object of the College being to train men for special service, the number is limited, and all admitted are, with a few exceptions, paid by the Government. During the first year the student is on probation, and receives his food and lodging only. He then gets an allowance of about three taels (I4s. or $15 s$. ) a month. In two or three years this stipend is doubled if the student progresses satisfactorily, and it is again increased to ten taels a month at the end of five or six years. If a student is sent to pursue his studies in foreign countries, the allowance is one hundred taels a month, which is increased to two hundred taels when he is made a third-class interpreter. The preparation of books for the diffusion of scientific and generai knowledge is part of the work of the College. Amongst those prepared and published already are works on natural philosophy, chemistry, practical economy, chemical analysis, mathematical physics, anatomy, astronomy, \&c.

IN the "Note" last week about a Greenland whale which went ashore in the Sound (p. 398), for "go feet in length" read " 60 feet in length."

THE additions to the Zoological Society's Gardens during the past week include a Macaque Monkey (Macacus cynomolgus $q$ ) from India, presented by Mrs. Nicol; an Indian Chevrotain (Tragulus meminna \& juv.) from India, presented by Mr. George Score; a Hybrid Polecat (between Mustela putorius and M. furo), British, presented by Mr. J. Herbert B. Cowley; an Owen's Apteryx (Apteryx oweni) from New Zealand, presented by Prof. T. Jeffrey Parker, C.M.Z.S.; a Common Buzzard (Buteo vulgaris) from Spain, presented by Captain J. V. Harvey; eight Common Swans (Cygnus olor), European, deposited ; seven Common Gulls (Larzes canus), from Holland, five White's Tree Frogs (Hyla ccerula) from Australia, purchased; a Collared Fruit Bat (Cynonycteris collaris), born in the Gardens.

\section{ASTRONOMICAL PHENOMENA FOR THE WEEK 1889 MARCH $3-9$.}

(FOR the reckoning of time the civil day, commencing at Greenwich mean midnight, counting the hours on to 24 , is here employed.)

\section{At Greenwich on March 3}

Sun rises, 6h. $42 \mathrm{~m}$.; souths, $12 \mathrm{~h}$. $12 \mathrm{~m} .3^{\circ}$ os. : sets, $17 \mathrm{~h} .42 \mathrm{~m}$. : right asc. on meridian, $22 \mathrm{~h} .57^{\circ} 9 \mathrm{~m}$; ; decl. $6^{\circ} 37^{\prime} \mathrm{S}$. Sidereal Time at Sunset, 4 h. $29 \mathrm{~m}$.

Moon (at First Quarter on March 9, I8h.) rises, 7h. $48 \mathrm{~m}$. souths, $13 \mathrm{~h} .35 \mathrm{~m}$. ; sets, 19h. $35 \mathrm{~m}$. : right asc. on meridian, oh. $20^{\circ} 7 \mathrm{~m}$.; decl. $3^{\circ} 6^{\prime} \mathrm{S}$.

Planet. Rises. Souths. Sets. Right asc. and declinatio $\begin{array}{llll}\text { Rises. } & \text { Souths. Sets. } & \text { on meridian. } \\ \text { h. m. } & \text { h. m. } & \text { h. m. h. m. }\end{array}$

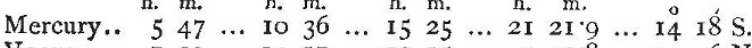
$\begin{array}{llllllllllllllllllll}\text { Venus..... } & 7 & 39 & \ldots & \text { 14 } & 57 & \ldots & 22 & \text { 1 } 5 & \ldots & \text { 1 } & 43.8 & \ldots & 14 & 6 & \mathrm{~N}\end{array}$ $\begin{array}{lllllllllllllllllllll}\text { Mars ....... } & 7 & 30 & \ldots & 13 & 54 & \ldots & 20 & 18 & \ldots & 0 & 40 & \ldots & \ldots & 3 & 56 & \mathrm{~N} .\end{array}$

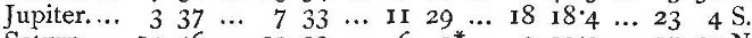
$\begin{array}{lllllllllllllllll}\text { Saturn.... } & 14 & 46 & \ldots & 22 & 23 & \ldots & 6 & 0^{*} \ldots & 9 & 10 & 9 & \ldots & 17 & 30 & \mathrm{~N}\end{array}$

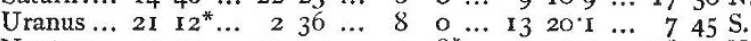
$\begin{array}{lllllllllllllllllllll}\text { Neptune.. } & 9 & 22 & \ldots & 17 & 5 & \ldots & 0 & 48^{*} \ldots & 3 & 51^{*} 4 & \ldots & 18 & 29 & \mathrm{~N} & \end{array}$ * Indicates that the rising is that of the preceding evening and the setting that of the following morning.

Mar. h.

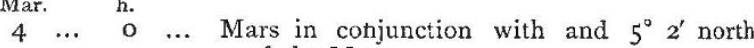
of the Moon.

$5 \quad \ldots \quad$ I I ... Venus in conjunction with and $8^{\circ} 57^{\prime}$ north of the Moon.

$\begin{array}{lllll}5 & \ldots & 20 & \ldots & \text { Venus at least distance from the Sun. }\end{array}$

Saturn, March 3.- Outer major axis of outer ring $=45^{\prime \prime} \cdot 2$; outer minor axis of outer ring $=12^{\prime \prime} 5$ : southern surface visible.

\section{Meteor-Showers. \\ R.A. Decl.}

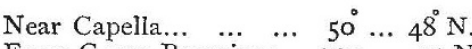

From Coma Berenices ... $190 \ldots .25$... 25 ... March 8.

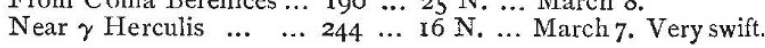




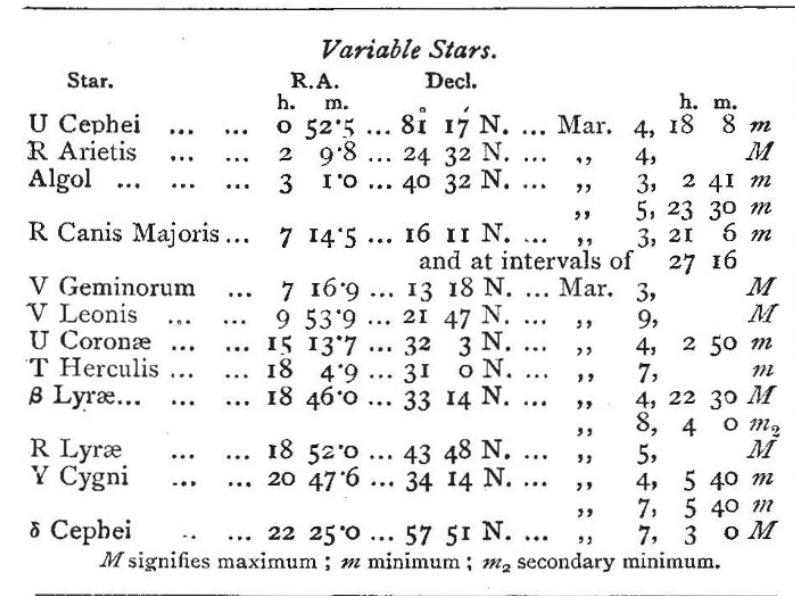

\section{GEOGRAPHICAL NOTES.}

THE paper read at Monday's meeting of the Royal Geographical Society was by Captain Vangèle, giving an account of his exploration of the Welle-Mobangi river, the great northern tributary of the Congo. His first exploration was made in the end of 1886 in a flat-bottomed boat, the Henry Read, with a stern paddle-wheel. On this first journey Captain Vangèle did not succeed in getting beyond Mr. Grenfell's furthest, the Zongé Falls, just where the river turns sharply to the east. He gives an interesting account of the Ba-Ati, the people who inhabit the banks of the river, and who are in every way of a superior type, though cannibals. A little distance ahove its mouth the Mobangi or Ubangi measures about 2730 yards in breadth ; its greatest depth is 5 fathoms, its lowest $\mathbf{I}$ fathom; it flows at the rate of $3 \frac{1}{4}$ feet a second. Under the 4 th degree, just below the rapids, it still has a breadth of 1300 yards, a depth of 4 fathoms, and a velocity of 4 feet a second. Between these two points, though continually varying in breadth, it never exceeds about 4000 yards, including the islands. The general appearance of the river is pretty much the same as that of the Congo near Bolobo-strewn with islands, and having low wooded banks. The colour of the water is a light brown. Captain Vangèle's second journey was made a year later, and with better means of forcing his way up the rapids of the Mobangi. This time, though he encountered several obstacles, he managed to push his way up the river to over $22^{\circ} \mathrm{E}$. longitude, and to within sixty miles of Junker's furthest point on the Wellé. This has been accepted as clearly proving the identity of these two rivers, so that the long-standing problem of the Wellé may be regarded as solved. At his furthest point!Captain Vangèle had to turn back owing to the hostility of the natives, the only instance in which the met with real opposition. Between rocks and islands, rapids and cataracts, the navigation of the lower Mobangi is beset with difficulties, though it is evidently practicable with suitable vessels, and a thorough knowledge of the river. The river is subject to great variations of level, according to the season of the year. Above the Zongo Falls, the people, named Bakombé, differ considerably from those on the lower river, and evidently spread far inland. From above the Zongo rapids the river opens out, flowing straight from the north-east, and the outlook is described as superb. It is free from all obstacles, from 900 to I000 yards wide, with a depth of $12 \frac{1}{2}$ fathoms, flowing between banks 6 to Io feet high, grassy plains alternating with clusters of trees. After thirty miles in the north east direction the river turns due east, which direction it maintained to the end of the voyage, I 7o miles. The banks are densely inhabited, and provisions of all kinds abound. Between the Zongo Falls and the steamer's furthest point only one tributary was met with-the Bangasso-coming from the north. After the paper was read, Sir Francis De Winton made some remarks with regard to the position of Mr. Stanley. He totally disbelieves the conjecture of Lieut. Baert that Stanley has any intention of taking Khartoum. On the contrary, Sir Francis believes he is now on his way home by the east coast.

IN the last issued number $\left(4^{\mathrm{e}}\right.$ trimestre, 1888$)$ of the Bulletin of the Paris Geographical Society will be found a very complete examination of the route for a proposed Euphrates Valley Railway, by M. A. Dumont. M. Adrien Blondel contributes a detailed account of the Island of Réunion. M. Tules Marcou, in concluding his paper on the origin of the name of America, decides against Vespucci and in favour of an aboriginal placename.

IT has been arranged that the eighth German Geographentagr shall be held at Berlin from April 24 to 26 next.

The Ceylon Observer states that Mr. Stephens, who has recently been amongst the Veddas of Ceylon, and who subsequently explored New Guinea, is now in Ceylon on his way to Singapore to organize an expedition at the instance of Prof. Virchow to explore the unknown portions of the Malayan Peninsula. Mr. Stephens's instructions are to start from Malacca and travel northnorth-west through the vast expanse of unexplored territory which stretches northwards for some 500 miles. There are on the coast various settlements near mines and plantations, but the greater portion of the interior has been hitherto unexplored. The inhabitants are said to be jealous and bloodthirsty.

\section{LEEWY'S INVENTIONS AND RESEARCHES. ${ }^{1}$}

$\mathrm{IT}^{\mathrm{T}}$ is now my pleasing duty to lay before you the grounds on which the Council have awarded the gold medal to $M$. Maurice Lœwy for his invention of the equatorial coudé, of a new method of determining the constant of aberration, and for his other astronomical researches.

On examining the series of memoirs in which M. Lœwy has set forth bis new methods of astronomical research, we are at once impressed by the originality of conception which characterizes all his ideas, and by the thoroughness with which he has worked out the details necessary for the practical application of his new methods of observation. Observational astronomy has for many years past proceeded on such well-defined lines, that we have not unnaturally come to look rather to improvements of detail than to the introduction of new instruments for the advancement of our knowledge. It is, therefore, a matter of great satisfaction to find that M. Lœwy has placed at our disposal various methods of observation based on entirely new principles, and calculated to give astronomers improved and quite independent means of attacking several of the most important problems in our science.

The first of these new instruments with which $I$ will deal is the equatorial coudé.

It was in the year 1871 that M. Lœwy proposed his new form of equatorial, to which the name of "equatorial coude" has been given, and M. Delaunay, then Director of the Paris Observatory, was so struck with the value of the principle that he arranged for the construction of an instrument on this plan. M. Delaunay's death, however, interrupted the work, and the first equatorial coudé, having an object-glass of 0.27 metre, or about $10_{8}^{5}$ inches aperture, was not completed till the year I882. The success of this instrument was so marked that its value could not fail to be recognized, and it was not long before the construction of several larger equatorials on the same principle was commenced. At the present time six equatorial coudés have been completed, and four of these are already mounted and in regular use at the Observatories of Paris, Lyons, Besançon, and Algiers. The other two are intended for the Observatories of Paris and Vienna.

In principle the equatorial condé may be described as an adaptation of the form of transit instrument with axial view to the requirements of an equatorial, by the addition of a plane mirror inclined at $45^{\circ}$ outside the object-glass, this mirror being capable of rotation about the axis of the telescope, so as to reflect into the latter the rays from any object in a perpendicular plane. The axis of the instrument is mounted as a polar axis between two piers, the telescope being broken at a right angle near the lower pivot, so that the rays from the object-glass are reflected by an internal mirror up the polar axis to the hollow upper pivot, where the image is formed. The rotation of the outer mirror thus brings into the field the image of any object in the hour-circle perpendicular to the object-end of the telescope, and by the rotation of the polar axis, as in an ordinary equatorial, the telescope is directed to any hour-angle. The declination-axis in the equatorial coudé is the axis of the objectend of the telescope about which the outer mirror turns, and the declination-circle placed at the eye-end, in the same plane with

I Address delivered by the President of the Royal Astronomical Society, Mr. W. H. M Christie, F.R.S.. Astronomer-Royal, on presenting the Gold Medal of the Society to M. M. Lowy at the anniversary meeting on February 8, 1889. 